\title{
Clinical features of seronegative, but CSF antibody-positive, anti-NMDA receptor encephalitis
}

Mar Guasp, MD, Yasmina Módena, BS, Thaís Armangue, MD, PhD, Josep Dalmau, MD, PhD, and Francesc Graus, MD, PhD

Neurol Neuroimmunol Neuroinflamm 2020;7:e659. doi:10.1212/NXI.0000000000000659
Correspondence

Dr. Graus

francesc.graus@idibaps.org

\section{Abstract}

\section{Objective}

To determine the frequency of anti-NMDA receptor encephalitis without detectable serum NMDAR antibodies and to compare the clinical features of these patients with those with NMDAR antibodies in serum and CSF.

\section{Methods}

This is a retrospective assessment of serum antibody status and clinical features of 489 patients with anti-NMDAR encephalitis, defined by the presence of NMDAR antibodies in the CSF, and available paired serum/CSF samples examined at Hospital Clínic-Institut d'Investigacions Biomèdiques August Pi I Sunyer, Barcelona, between January 2007 and December 2017. NMDAR antibodies were determined with rat brain immunostaining, in-house cell-based assay (CBA), and a commercial CBA. Patients were considered seronegative if NMDAR antibodies were undetectable with the 3 indicated techniques.

\section{Results}

Serum NMDAR antibodies were not detected in 75 of 489 (15\%) patients. Compared with the 414 seropositive patients, the seronegative were older (23.5 years [interquartile range (IQR): $17-43$ ] vs 20.5 [IQR: $14-31$ ]; $p<0.0001)$ and less frequently women (39 [52\%] vs 313 [76\%]; $p<0.001)$ and had less tumors (6 [9\%] vs $128[32 \%] ; p<0.001)$. In multivariate analysis, older age at diagnosis (odds ratio [OR]: 1.35 [per decade]; 95\% confidence interval [CI]: 1.10-1.67), absence of tumor (OR: 0.14; 95\% CI: 0.05-0.43), and less need for intensive care unit admission (OR: 0.35 ; 95\% CI: $0.18-0.69$ ) were independent variables associated with the absence of serum NMDAR antibodies. Time to diagnosis, treatment with immunotherapy, relapses, and outcome were similar in seronegative and seropositive patients.

\section{Conclusions}

NMDAR antibodies are not detected in the serum of $15 \%$ of the patients with anti-NMDAR encephalitis. These patients appear to be older and have milder neurologic symptoms with less frequency of tumors. 


\section{Glossary}

$\mathbf{A C h R}=$ acetylcholine receptor; $\mathbf{C B A}=$ cell-based assay; $\mathbf{C I}=$ confidence interval; $\mathbf{I C U}=$ intensive care unit; IDIBAPS = d'Investigacions Biomèdiques August Pi I Sunyer; mRS = modified Rankin Scale; OR = odds ratio.

Early recognition of anti-NMDA receptor encephalitis can be challenging because the initial symptoms may resemble viral encephalitis or a primary psychiatric disorder. ${ }^{1}$ Although the need to test the CSF for NMDAR antibodies has been emphasized in previous reports and several guidelines, NMDAR antibodies are often determined only in the serum. ${ }^{2,3}$ A previous study showed that serum NMDAR antibody testing was negative in $14 \%$ of the patients with anti-NMDAR encephalitis who had NMDAR antibodies in the CSF, but the associated symptoms and potential prognostic implications were not investigated. ${ }^{4}$ Here, we first determined the frequency of seronegative antiNMDAR encephalitis, and we then assessed whether the clinical features and outcomes of these patients were different from those with NMDAR antibodies in the serum and CSF.

\section{Methods}

\section{Patients}

We retrospectively assessed from our database in Hospital Clínic-Institut d'Investigacions Biomèdiques August Pi I Sunyer (IDIBAPS), Barcelona, cases of patients with antiNMDAR encephalitis studied between January 2007 and December 2017, who had (1) clinical features of anti-NMDAR encephalitis and positive NMDAR antibodies in the $\mathrm{CSF}^{2}$ (2) paired serum-CSF samples obtained before the onset of immunotherapy, and (3) available clinical information. Clinical information was obtained at different time points during the course of the disease using written questionnaires as reported. ${ }^{1}$

\section{NMDAR antibody determination}

NMDAR antibodies were detected using 3 different techniques: (1) immunohistochemistry on frozen sections of rat brain postfixed with paraformaldehyde (serum dilution 1/ 200), (2) in-house cell-based assay (CBA) with fixed HEK293 cells transfected with NMDAR GluN1/N2B subunits (serum dilution 1/40), and (3) commercial CBA with fixed HEK293 cells (serum dilution 1/10) following the manufacturers' instructions (Euroimmun, Lübeck, Germany). Details of each technique have been reported in the indicated studies. ${ }^{4-6}$ All samples were initially tested with brain immunohistochemistry and in-house CBA by investigators blinded to the results of each technique. Those that were NMDAR antibody negative by immunohistochemistry and in-house CBA were additionally evaluated by a commercial CBA. A serum was considered negative for NMDAR antibodies if it was found negative with all 3 techniques.

\section{Statistical analysis}

Demographic information and clinical and immunologic features comparing seronegative and seropositive patients were analyzed with Fisher exact test, $\chi^{2}$ test, or MannWhitney $U$ test when appropriate. Outcome analysis at the last follow-up was assessed with the modified Rankin Scale (mRS) by an investigator blinded to the result of the serologic studies. Patients were considered to have a good outcome if the mRS score at the last follow-up was $0-2$ and a poor outcome if the mRS score was higher than 2. Variables associated with seronegativity on univariate analysis ( $p$-value < 0.05 ) were included in a multivariate binary logistic regression model and approached by a forward stepwise procedure; variables were considered independent when they remained statistically significant. Odds ratio with $95 \%$ confidence in terval was used to measure the effect of independent variables. Stata version 13.1 statistical software (StataCorp LP, TX) was used for the analyses.

\section{Standard protocol approvals, registrations, and patient consents}

Patients' serum and CSF samples are deposited in the collection of biological samples named "Neuroinmunología" registered in the Biobank of IDIBAPS. The Ethics Committee of the Hospital Clínic approved the study. All patients or proxies gave written informed consent for the storage and use of serum, CSF, and clinical information for research purposes.

\section{Data availability}

All data are reported within the article and available anonymized by request from qualified investigators.

\section{Results}

Seventy-five (15.3\%) of 489 patients with well-defined antiNMDAR encephalitis did not have antibodies in the serum (only had antibodies in the CSF), and the other 414 (84.7\%) had antibodies in both serum and CSF (seropositive). Among these 414 cases, 340 (82\%) had antibodies in the serum using brain immunohistochemistry and in-house CBA, 57 (14\%) with only 1 of these 2 techniques, and 17 (4\%) were negative with both techniques but positive with the commercial CBA. A summary of the clinical characteristics of both cohorts is shown in table. Compared with seropositive patients, the seronegative cases were older at disease onset (median age at disease onset: 23.5 years [interquartile range (IQR): 17-43] vs 20.5 years [IQR: $14-31$ ]; $p<0.0001$ ), less frequently women (39 [52\%] vs $313[76 \%] ; p<0.001)$, and with a lower frequency of tumors: $6(9 \%)$ vs $128(32 \%) ; p<0.001$. During the course of the disease, seronegative patients were less likely to develop seizures (44[60\%] vs $294[73 \%] ; p=0.028$ ), movement disorders $(52[69 \%]$ vs $355[86 \%] ; p<0.001)$, and central hypoventilation (12 [16\%] vs $132[32 \%] ; p=0.008)$. 
Table Demographic, clinical characteristics, and outcomes of the whole series of anti-NMDAR encephalitis and according to anti-NMDAR serostatus

\begin{tabular}{|c|c|c|c|c|}
\hline & All $(n=489)(\%)$ & Seronegative $(n=75)(\%)$ & Seropositive $(n=414)(\%)$ & $p$ Value \\
\hline Median age (IQR), y & $20.5(14-31)$ & $23.5(17-43)$ & $20.5(13-29)$ & $<0.0001$ \\
\hline Female sex & $352(72)$ & $39(52)$ & $313(76)$ & $<0.001$ \\
\hline Caucasian ethnicity & $219(46)$ & $39(55)$ & $180(45)$ & 0.118 \\
\hline $\begin{array}{l}\text { Median interval between symptom onset } \\
\text { and antibody testing (IQR), d }\end{array}$ & $35(21-60)$ & $30(21-60)$ & $35(21-63)$ & 0.3792 \\
\hline Prodromal symptoms ${ }^{a}$ & $230(51)$ & $39(56)$ & $191(51)$ & 0.437 \\
\hline \multicolumn{5}{|l|}{ Main symptoms } \\
\hline Behavioral and cognitive & $466(95)$ & $71(95)$ & $395(95)$ & 0.779 \\
\hline Memory impairment & $337(74)$ & $53(78)$ & $284(73)$ & 0.429 \\
\hline Speech disorder & $374(79)$ & $53(77)$ & $321(80)$ & 0.591 \\
\hline Seizures & $338(71)$ & $44(60)$ & $294(73)$ & 0.028 \\
\hline Decreased level of consciousness & $330(69)$ & $53(74)$ & $277(69)$ & 0.392 \\
\hline Movement disorder & $407(83)$ & $52(69)$ & $355(86)$ & $<0.001$ \\
\hline Autonomic dysfunction & $248(51)$ & $34(47)$ & $214(52)$ & 0.420 \\
\hline ICU stay & $310(65)$ & $27(43)$ & $283(69)$ & $<0.001$ \\
\hline Abnormal brain MRI & $147(32)$ & $30(43)$ & $117(30)$ & 0.025 \\
\hline Median (IQR) CSF white blood cell count per $\mathrm{mm}^{3}$ & $19(3-52)$ & $17(4-50)$ & $20(3-54)$ & 0.9896 \\
\hline Normal EEG & $71(16)$ & $13(19)$ & $58(15)$ & 0.632 \\
\hline Tumor & $134(29)$ & $6(9)$ & $128(32)$ & $<0.001$ \\
\hline Teratoma & $125(27)$ & $4(6)$ & $121(31)$ & $<0.001$ \\
\hline Second line treatment & $117(41)$ & $23(38)$ & $94(43)$ & 0.498 \\
\hline Median (IQR) delay to treatment (in d) & $21(14-35)$ & $22(14-35)$ & $21(14-35)$ & 0.5443 \\
\hline Relapses & $37(12)$ & $9(16)$ & $28(11)$ & 0.307 \\
\hline Bad outcome (mRS $>2$ ) at 12 months & $68(26)$ & $8(19)$ & $60(27)$ & 0.265 \\
\hline
\end{tabular}

Abbreviations: ICU = intensive care unit; IQR = interquartile range; $\mathrm{mRS}=$ modified Rankin Scale.

a Fever, headache, flu-like symptoms, or gastrointestinal symptoms (vomiting/diarrhea).

Intensive care unit (ICU) admission was also less frequently required in the seronegative cohort: $27(43 \%)$ vs $283(69 \%)$; $p<0.001$ (table). In multivariate analysis, older age at diagnosis (OR: 1.35 [per decade]; 95\% CI: 1.10-1.67), absence of tumor (OR: 0.14; 95\% CI: 0.05-0.43), and less need for ICU admission (OR: 0.35; 95\% CI: 0.18-0.69) were independent variables associated with the absence of NMDAR antibodies.

\section{Discussion}

We retrospectively identified that $15 \%$ of the patients with anti-NMDAR encephalitis did not have antibodies in the serum, only had antibodies in the CSF, and that these patients were less likely to be women, have an underlying tumor, and develop seizures, movement disorders, central hypoventilation, or admission to ICU.

In a routine clinical diagnosis, the frequency of seronegative cases may even increase because samples are usually tested by a single technique without the expertise of a reference laboratory. There are 2 possible explanations for the apparent absence of NMDAR antibodies in the serum. The first is that the titer of NMDAR-abs is below the threshold of detection using the indicated techniques. ${ }^{4}$ There is precedence for this in a subset of patients with myasthenia gravis who did not have detectable acetylcholine receptor (AChR) antibodies by routine commercial radioimmunoassays, but the antibodies could be detected by a CBA that expressed AChRs clustered by rapsyn. ${ }^{7}$ Alternatively, seronegative patients, or a subset of them, may have NMDAR 
antibodies only in the CSF after systemically activated $\mathrm{T}$ and $\mathrm{B}$ cells cross the blood-brain barrier and orchestrate the synthesis of NMDAR antibodies in the brain, reflected by an almost constant presence of intrathecal NMDAR antibody synthesis and plasma cells in perivascular, interstitial, and Virchow-Robin spaces. ${ }^{8,9}$ These patients could potentially have transient low levels of antibodies in the serum, which become rapidly negative or below the threshold of detection. Against the later possibility is the presence, although with a lower frequency compared with seropositive patients, of a systemic NMDAR-expressing tumor, such as a teratoma (usually infiltrated by lymphocytes that can synthesize NMDAR antibodies) in $6 \%$ of the seronegative patients, and the observation in previous studies that the presence of a teratoma associates with higher titers of serum NMDAR antibodies. ${ }^{4}$

We postulate that seronegative patients have a less robust immune response in the CNS, probably reflecting the more benign clinical features of the disease. A similar observation was made in patients with apparently seronegative myasthenia gravis (antibodies detected by CBA with clustered AChR) who also had milder symptoms compared with overly seropositive patients. ${ }^{10} \mathrm{~A}$ task for the future is to determine whether seronegative patients have lower titers of CSF antibodies compared with seropositive cases.

Our findings increase awareness of a subset of patients with anti-NMDAR encephalitis who are antibody negative in the serum and appear to have a milder form of the disease. Thus, the absence of serum NMDAR antibodies in patients with suspected anti-NMDAR encephalitis does not rule out this diagnosis, and these patients should be tested for CSF antibodies. Because the outcome and frequency of relapses at 12 months were similar to those of seropositive patients, the current findings suggest that until larger and prospective studies become available, the seronegative NMDAR antibody patients with anti-NMDAR encephalitis should be treated similarly as the seropositive ones.

\section{Acknowledgment}

The authors thank Mrs. Esther Aguilar and Mrs. Eva Caballero for her excellent technical support.

\section{Study funding}

This study was supported in part by Plan Nacional de I+D+I and cofinanced by the ISCIII - Subdirección General de Evaluación y Formento de la Investigación Sanitaria - and the Fondo Europeo de Desarrollo Regional (ISCIII-FEDER; PI18-00486, TA; 17/00,234, JD); the Mutua Madrileña Foundation (AP162572016, TA); Pla estratègic de recerca i innovació en salut (PERIS), Departament de Salut, Generalitat de Catalunya (SLT006/17/00,362, TA); NIH RO1NS077851 (JD) and Fundació Cellex (JD). Dr. Guasp is a recipient of a Resident Award "Josep Font", granted by Hospital Clínic de Barcelona, Research, Innovation and Education Departments.

\section{Disclosure}

M. Guasp reports no disclosures. Y. Módena reports no disclosures. T. Armangue reports no disclosures. J. Dalmau receives royalties from Athena Diagnostics for the use of $\mathrm{Ma} 2$ as an autoantibody test and from Euroimmun for the use of NMDA, GABAB receptor, GABAA receptor, DPPX and IgLON5 as autoantibody tests. F. Graus receives royalties from Euroimmun for the use of IgLON5 as an autoantibody test and honoraria for Assistant Editor of MedLink Neurology. Go to Neurology.org/NN for full disclosures.

\section{Publication history}

Received by Neurology: Neuroimmunology \& Neuroinflammation November 5, 2019. Accepted in final form December 1, 2019.

\section{Appendix Authors}

\begin{tabular}{|c|c|c|c|}
\hline Name & Location & Role & Contribution \\
\hline $\begin{array}{l}\text { Mar Guasp, } \\
\text { MD }\end{array}$ & $\begin{array}{l}\text { Hospital Clínic, } \\
\text { Barcelona, Spain }\end{array}$ & Author & $\begin{array}{l}\text { Design and } \\
\text { conceptualization of } \\
\text { the study; acquisition } \\
\text { and review of } \\
\text { clinical data; } \\
\text { immunohistochemical } \\
\text { studies; analysis and } \\
\text { interpretation of the } \\
\text { data; drafted the first } \\
\text { version of the } \\
\text { manuscript; revised } \\
\text { the manuscript for } \\
\text { intellectual content. }\end{array}$ \\
\hline
\end{tabular}

\begin{tabular}{|c|c|c|c|}
\hline $\begin{array}{l}\text { Yasmina } \\
\text { Módena, BS }\end{array}$ & $\begin{array}{l}\text { IDIBAPS, Barcelona, } \\
\text { Spain }\end{array}$ & Author & $\begin{array}{l}\text { Immunohistochemical } \\
\text { studies and cell-based } \\
\text { assays; revised the } \\
\text { manuscript for } \\
\text { intellectual content. }\end{array}$ \\
\hline $\begin{array}{l}\text { Thaís } \\
\text { Armangue, } \\
\text { MD, PhD }\end{array}$ & $\begin{array}{l}\text { IDIBAPS, Hospital } \\
\text { Clínic, SJD } \\
\text { Children's Hospital, } \\
\text { Barcelona, Spain }\end{array}$ & Author & $\begin{array}{l}\text { Statistical analysis and } \\
\text { interpretation of the } \\
\text { data; revised the } \\
\text { manuscript for } \\
\text { intellectual content. }\end{array}$ \\
\hline $\begin{array}{l}\text { Josep } \\
\text { Dalmau, } \\
\text { MD, PhD }\end{array}$ & $\begin{array}{l}\text { Hospital Clínic, } \\
\text { ICREA Barcelona, } \\
\text { Spain and } \\
\text { University of } \\
\text { Pennsylvania, PA }\end{array}$ & Author & $\begin{array}{l}\text { Analysis and } \\
\text { interpretation of the } \\
\text { data; revised the } \\
\text { manuscript for } \\
\text { intellectual content. }\end{array}$ \\
\hline $\begin{array}{l}\text { Francesc } \\
\text { Graus, MD, } \\
\text { PhD }\end{array}$ & $\begin{array}{l}\text { IDIBAPS, Barcelona, } \\
\text { Spain }\end{array}$ & Author & $\begin{array}{l}\text { Design and } \\
\text { conceptualization of } \\
\text { the study; review of } \\
\text { clinical data; drafted } \\
\text { the first version of } \\
\text { the manuscript; } \\
\text { revised the manuscript } \\
\text { for intellectual } \\
\text { content. }\end{array}$ \\
\hline
\end{tabular}

\section{References}

1. Titulaer MJ, McCracken L, Gabilondo I, et al. Treatment and prognostic factors for long-term outcome in patients with anti-NMDA receptor encephalitis: an observational cohort study. Lancet Neurol 2013;12:157-165.

2. Graus F, Titulaer MJ, Balu R, et al. A clinical approach to diagnosis of autoimmune encephalitis. Lancet Neurol 2016;15:391-404.

3. Irani SR, Bera K, Waters $\mathrm{P}$, et al. N-methyl-D-aspartate antibody encephalitis: temporal progression of clinical and paraclinical observations in a predominantly non-paraneoplastic disorder of both sexes. Brain 2010;133: $1655-1667$. 
4. Gresa-Arribas N, Titulaer MJ, Torrents A, et al. Antibody titres at diagnosis and during follow-up of anti-NMDA receptor encephalitis: a retrospective study. Lancet Neurol 2014;13:167-177.

5. Dalmau J, Tüzün E, Wu HY, et al. Paraneoplastic anti- $N$-methyl-D-aspartate receptor encephalitis associated with ovarian teratoma. Ann Neurol 2007;61:25-36.

6. Dalmau J, Gleichman AJ, Hughes EG, et al. Anti-NMDA-receptor encephalitis: case series and analysis of the effects of antibodies. Lancet Neurol 2008;7:1091-1098.

7. Leite MI, Jacob S, Viegas S, et al. IgG1 antibodies to acetylcholine receptors in 'seronegative' myasthenia gravis. Brain 2008;131:1940-1952.
8. Dalmau J, Lancaster E, Martinez-Hernandez E, Rosenfeld MR, Balice-Gordon R. Clinical experience and laboratory investigations in patients with anti-NMDAR encephalitis. Lancet Neurol 2011;10:63-74.

9. Martinez-Hernandez E, Horvath J, Shiloh-Malawsky Y, et al. Analysis of complement and plasma cells in the brain of patients with anti-NMDAR encephalitis. Neurology 2011;77:589-593.

10. Rodriguez Cruz PM, Al-Hajjar M, Huda S, et al. Clinical features and diagnostic usefulness of antibodies to clustered acetylcholine receptors in the diagnosis of seronegative myasthenia gravis. JAMA Neurol 2015;72:642-649. 


\title{
Neurology \\ Neuroimmunology \& Neuroinflammation
}

\author{
Clinical features of seronegative, but CSF antibody-positive, anti-NMDA receptor \\ encephalitis \\ Mar Guasp, Yasmina Módena, Thaís Armangue, et al. \\ Neurol Neuroimmunol Neuroinflamm 2020;7; \\ DOI 10.1212/NXI.0000000000000659
}

This information is current as of January 3,2020

\section{Updated Information \& \\ Services \\ References \\ Citations \\ Subspecialty Collections}

Permissions \& Licensing

Reprints including high resolution figures, can be found at:

http://nn.neurology.org/content/7/2/e659.full.html

This article cites 10 articles, 0 of which you can access for free at: http://nn.neurology.org/content/7/2/e659.full.html\#\#ref-list-1

This article has been cited by 7 HighWire-hosted articles: http://nn.neurology.org/content/7/2/e659.full.html\#\#otherarticles

This article, along with others on similar topics, appears in the following collection(s):

All Clinical Neurology

http://nn.neurology.org//cgi/collection/all_clinical_neurology Autoimmune diseases

http://nn.neurology.org//cgi/collection/autoimmune_diseases Encephalitis

http://nn.neurology.org//cgi/collection/encephalitis

Information about reproducing this article in parts (figures,tables) or in its entirety can be found online at:

http://nn.neurology.org/misc/about.xhtml\#permissions

Information about ordering reprints can be found online:

http://nn.neurology.org/misc/addir.xhtml\#reprintsus

Neurol Neuroimmunol Neuroinflamm is an official journal of the American Academy of Neurology.

Published since April 2014, it is an open-access, online-only, continuous publication journal. Copyright

Copyright $\odot 2020$ The Author(s). Published by Wolters Kluwer Health, Inc. on behalf of the American

Academy of Neurology.. All rights reserved. Online ISSN: 2332-7812.

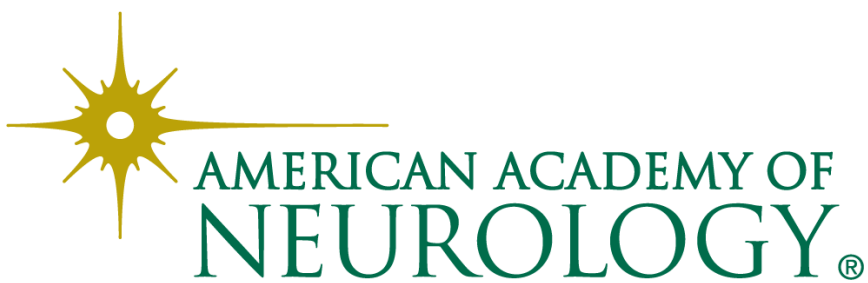

